\title{
Diet and ecomorphology of predator fish species of the Amazonian floodplain lakes
}

\author{
Diogo Campos Cardoso ${ }^{I}$, Pieter deHart ${ }^{2}$, Carlos Edwar de Carvalho Freitas ${ }^{I}$ \& Flávia Kelly Siqueira-Souza ${ }^{1 * \text { [D }}$ \\ ${ }^{1}$ Universidade Federal do Amazonas, Departamento de Ciências Pesqueiras, Manaus, AM, Brasil \\ ${ }^{2}$ Unity College, School of Environmental Citizenship, Maine, USA \\ *Corresponding author: Flávia Kelly Siqueira-Souza, e-mail: flaviasouza@ufam.edu.br
}

\begin{abstract}
CARDOSO, D.C., deHART, P., FREITAS, C.E.C., SIQUEIRA-SOUZA, F.K. Diet and ecomorphology of predator fish species of the Amazonian floodplain lakes. Biota Neotropica. 19(3): e20180678. http://dx.doi.org/10.1590/1676-0611-BN-2018-0678
\end{abstract}

\begin{abstract}
Amazonian floodplain lakes host a high diversity of predatory fish which coexist and exploit the high diversity of available prey. Morphology could be the characteristic most closely associated with their preferred feeding sources (prey). However, it is unclear whether this association is direct or indirect. If it is indirect, swimming performance or preferential position in the water column could be the most evident characteristic. To examine the degree to which fish morphology of predator fish species is correlated to their dietary inputs, we compared the existence of morphological and feeding dissimilarity among eight predator species with the association between predator morphologies and preferred prey. We collected, measured, and sampled the stomach contents of fish from two lowland floodplain lakes associated with the Solimões River, Brazil, in May, August, and November of 2014. Of 187 collected fish across eight species, five species showed fish to be the most important item in their diets and three preferentially ate shrimp. Principal components analyses of ecomorphological attributes divided the species according to their ability to find the prey, swimming performance of the predator, and prey size. While there was significant distinction between the varying morphologies of predators, we were unable to distinguish between the specific diet of these species and did not find a correlation between morphology and feeding. These results are likely due to the fact that there is great abundance and diversity of available prey in the Amazonian floodplain lakes, so opportunistic feeding may be the primary foraging strategy of predator fish species living in these environments. Keywords: Feeding behavior, Morphological Attributes, Predation, Amazonian floodplain lakes.
\end{abstract}

\section{Dieta e ecomorfologia de peixes predadores em lagos de várzea da Amazônia}

Resumo: Os lagos da várzea amazônica abrigam uma elevada riqueza de peixes predadores, com características morfológicas distintas, possibilitando explorar com sucesso várias presas disponíveis. Estas características morfológicas podem ser a associação mais próxima com suas fontes de alimentação preferidas (presa). Todavia, esta associação pode ser de forma direta ou indireta. Neste último caso, o desempenho da natação ou a posição preferencial na coluna d'água pode ser uma característica mais evidente. Para examinar o grau com que a morfologia de peixes predadores está correlacionada com seus itens alimentares, foram comparadas a existência de dissimilaridade morfológica e de alimentação entre oito espécies predadoras e a associação entre suas morfologias e suas presas. Foram coletados, medidos e amostrados o conteúdo estomacal de peixes de dois lagos de várzea associados ao rio Solimões, nos meses de maio, agosto e novembro de 2014. Dos 187 peixes coletados, em oito espécies, cinco mostraram que peixe era o item mais importante em suas dietas e três apresentaram preferência por camarão. A análise dos componentes principais dos atributos ecomorfológicos dividiu as espécies de acordo com a capacidade de encontrar sua presa, o desempenho de natação do predador e o tamanho da presa. Embora apresentasse distinção significativa entre suas características morfológicas, não foi encontrado distinção entre a dieta dessas espécies e nem correlação entre morfologia e alimentação. Esses resultados provavelmente se devem ao fato de que há grande abundância e diversidade de presas disponíveis nos lagos da planície de inundação da Amazônia, de modo que a alimentação oportunista pode ser a principal estratégia de forrageamento das espécies de peixes predadores que vivem nesses ambientes.

Palavras-chave: Comportamento alimentar, Atributos Morfológicos, Predação, Lagos de várzea amazônicos. 


\section{Introduction}

The Amazon basin displays strong spatial heterogeneity (LoweMcConnell 1999) coupled to marked seasonal changes associated with the hydrological cycle (Junk et al. 1989). This huge and highly dynamic environment hosts the highest freshwater fish diversity on Earth, with more than 2,411 fish species already described (Reis et al. 2016). Floodplain lakes adjacent to whitewater rivers are important components of the Amazon basin landscape, are the most productive area of the basin (Junk et al. 2011), and encompass several habitats that should be considered when studying fish diversity (Saint-Paul et al. 2000, Freitas et al. 2014, Siqueira-Souza et al. 2016a).

Amazonian fish evolved to display several morphological, behavioral, and physiological adaptations to successfully exploit the habitats of floodplain areas (Val \& Almeida-Val 1995, Freitas et al. 2010), including areas of open-water, macrophyte meadows, and flooded forests. Each of these habitats change greatly over the year as a consequence of the flood pulse (Junk et al. 1989) and subsequently show perceptible effects on fish assemblages (Siqueira-Souza et al. 2016a). The environmental changes of the Amazonian floodplain areas are dictated by variations in water level, have been associated with the life history strategies of fishes living in these areas (Sanchez-Botero et al. 2003, Anjos et al. 2008, Correa et al. 2008, Duarte et al. 2010). Ultimately these environmental changes determine food availability (Soares et al. 1986, Winemiller 1989, Mérona \& Rankin-de-Mérona 2004, Carvalho et al. 2017).

The diet of fish species is strongly driven by both the availability of prey items (Winemiller 1989, Wootton 1990, Luz-Agostinho et al. 2008, Correa \& Winemiller 2014) and the ability of predator species to capture prey (Schoener 1971, Agostinho et al. 1997, Abrams 2006). This ability is dependent on specific morphological adaptations (Adite \& Winemiller 1997, Hugueny \& Pouilly 1999, Pouilly et al. 2003, Teixeira \& Bennemann 2007, Mazzoni et al. 2010, Pagotto et al. 2011, Siqueira-Souza et al. 2016b). The relationships between morphology and feeding behavior are addressed through an examination of ecomorphology (Wikramanayake 1990, Winemiller 1991, Teixeira \& Bennemann 2007, Mazzoni et al. 2010, Sampaio et al. 2013). Ecomorphological studies have shown a relationship between feeding items and mouth size or position and the type and size of their prey (Gatz Jr. 1979, Piorski et al. 2005, Cochran-Biderman \& Winemiller 2010), as well as between size and shape of fins and swimming or maneuverability (Keast \& Webb 1966, Gatz Jr. 1979). In the Amazon basin, multiple research groups have already employed an ecomorphological analysis approach on Amazonian fish groups to elucidate the ecological relationships between feeding behavior, swimming ability, and habitat use preferences with morphology (e.g., Pouilly et al. 2003, Freitas et al. 2005, Siqueira-Souza et al. 2016b).

The biotic interactions most commonly associated with fish assemblage structure are competition and predation (Winemiller 1989, Rodriguez \& Lewis 1997). The importance of predation as a driver for fish assemblage structure is well-established (Wootton 1990, Csányi \& Dóka 1993, Nowlin et al. 2006, Heinlein et al. 2010), including for Neotropical basins (Rodríguez \& Lewis 1997, Okada et al. 2003, Petry et al. 2010). Predation has been shown to not only promote more rapid evolutionary change through the removal of more vulnerable animals (Nowlin et al. 2006) but can also clearly affect prey behavior (Wootton 1990). The fish diversity in Amazonian floodplain areas could be related to biotic interactions, such as predation, since around $30 \%$ of fish species living in these areas are carnivorous (Freitas et al. 2010). Nevertheless, the mechanisms acting to promote this high level of coexistence of species with similar niches have yet to be clearly identified. Dias et al. (2017) studied fish assemblages of the Paraná River floodplain and proposed that predator selectivity and feeding overlap are mediated by food availability, but they did not consider morphological aspects of these predators. In this study, we aim to fill these research gaps by addressing the following questions: Is there a correlation between morphology and diet of Amazonian predator fish? Do predatory fish uniformly share the feeding items? Are the ecomorphological characteristics similar among predator fish species? There are two opposing processes that potentially mediating the coexistence of these predatory species which could be identified with the answer to these questions: (i) the availability of prey is limited and predators need to develop strategies to avoid a over-predation of some specific preys, where in turn we would expect a high correlation between morphology and diet; and (ii) the availability of prey is high and fish morphologies are determined by phylogenetic process.

\section{Material and Methods}

\section{Study area}

Fish were collected at two floodplain lakes on the lower stretch of the Solimões River (Amazon Basin): Sacambú (-3.306744S, -60.243298W) and Central (-3.253823S, -59.970098W) lakes (Fig. 1), in May, August and November of 2014. Both are typical floodplain lakes, remaining connected with the Solimões River during high water season (May through July) and disconnected during low water season (October through December) (Junk et al. 1989). As island floodplain lakes, they are originated by the strong fluvial dynamic of the Solimões River (Carvalho et al. 2001, Siqueira-Souza et al. 2016a).

\section{Sampling}

Eight fish species abundant in Amazonian floodplain lakes were chosen and assigned as carnivorous with tendency to piscivory (Mérona \& Rankin-de-Mérona 2004, Soares et al. 2007, Anjos et al. 2008), nominally: Pygocentrus nattereri (Kner 1858), Serrasalmus rhombeus (Linnaeus 1766), Rhaphiodon vulpinus (Spix \& Agassiz 1829), Hydrolycus scomberoides (Cuvier 1816), Plagioscion squamosissimus (Heckel 1840), Cichla monoculus (Spix \& Agassiz 1831), Acestrorhynchus falcirostris (Cuvier 1819) and Hoplias malabaricus (Bloch 1794).

The fish samples in each lake were realized in three types of habitat: open water; aquatic macrophytes, predominantly composed of Pistia stratiotes, Eichhornia crassipes, Paspalum repens and Paspalum fasciculatum; and flooded forest, used by several species for shelter and feeding. Fish were caught with gillnets of standardized dimensions (15 $\times 2$ meters) and mesh sizes of 30, 40, 50, 60, 70, 80, 90, 100, 110 and $120 \mathrm{~mm}$ between opposite knots. Three groups of identical gillnets were simultaneously deployed in three different places on each lake. Additionally, we deployed line and hook baited with freshwater shrimp to catch C. monoculus. Captured fish were subsequently euthanized with thermal shock, identified, and stored on ice. After capture, all samples were then transported to the Laboratory of Fish Ecology, at the Federal University of Amazonas, for stomach content analyses and morphometric measurement. 


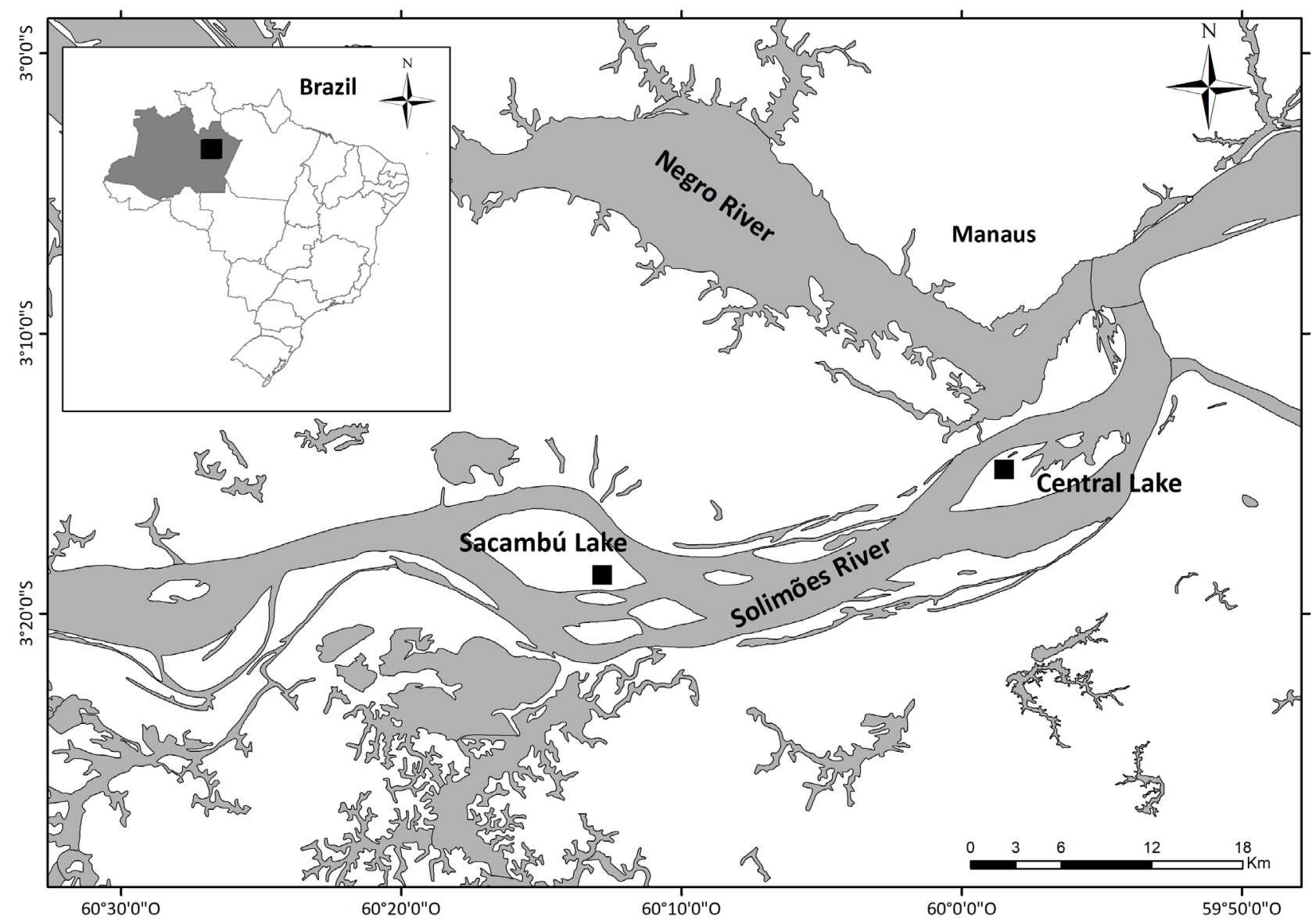

Figure 1. Study area indicating the two floodplain lakes on the lower stretch of the Solimões River: Lake Sacambú and Lake Central (Amazon Basin, Brazil), where fishes were collected.

\section{Ecomorphological attributes}

Ecomorphological analyses were conducted on captured adult fish, classified using the $\mathrm{L}_{50}$ of the species when references were available (Vazzoler 1996, Amadio \& Bittencourt 2005) or working only with largest individuals, so as to avoid potentially misleading characteristics of different/earlier developmental stages. We took a total of 18 different morphometric measures on each fish, with the aid of an ichthyometer and a caliper with an accuracy of $0.01 \mathrm{~m}$ (Fig 2), following pre-established protocols from the literature (Gatz Jr. 1979, Watson \& Balon 1984, Wikramanayake 1990, Winemiller 1991). These morphometric measures were then employed to estimate 13 ecomorphological attributes, which could reflect the trophic ecology of the species with clearly delineated interpretations (Table 1).

\section{Dietary analysis}

Stomachs were taken after a ventral incision. Feeding items were identified using a stereomicroscope and clustered into five categories: fish (including scales, bones, fins, and complete fish), shrimp, insect, fruit/seed, and others (i.e., botanical and animal material which could not be included into the previous categories, such as roots of macrophyte plants, feathers, etc.).

To estimate the relative contribution of each feeding item, we employed the modified points method (Catella \& Petrere Jr. 1996), to obtain the proportion of each feeding item in relation to the total stomach content, and the index of occurrence frequency (IOF), reporting both in percentage (Hynes 1950, Hyslop 1980). After this calculation, we estimated the index of feeding importance (IFI), substituting the volume percentage by estimated percentage of point method for each item following the technique of Kawakami \& Vazzoler (1980). Given that shrimp was used as bait for the capture of C. monoculus, this item was included only if there was more than one individual found in the stomach content.

\section{Data analysis}

Two Principal Component Analyses (PCA) were performed to order fish species by feeding items and ecomorphological attributes. The first PCA treated fish species as objects and IFI as descriptors. The second PCA maintained fish species as objects and estimated ecomorphological attributes as descriptors. The interpreted principal components were those with eigenvalues higher than broken-stick estimates (McCune \& Mefford 1997), since this criterion selects only the axis with eigenvalues higher than would be randomly expected (King \& Jackson 1999). Two PerMANOVA were performed. The first was conducted to test the hypothesis of identical feeding item partitioning among species, using a matrix of Bray-Curtis distance based on the relative volume of each feeding item. The second was performed to test the hypothesis of identical morphologies among species. It was based on a matrix of 


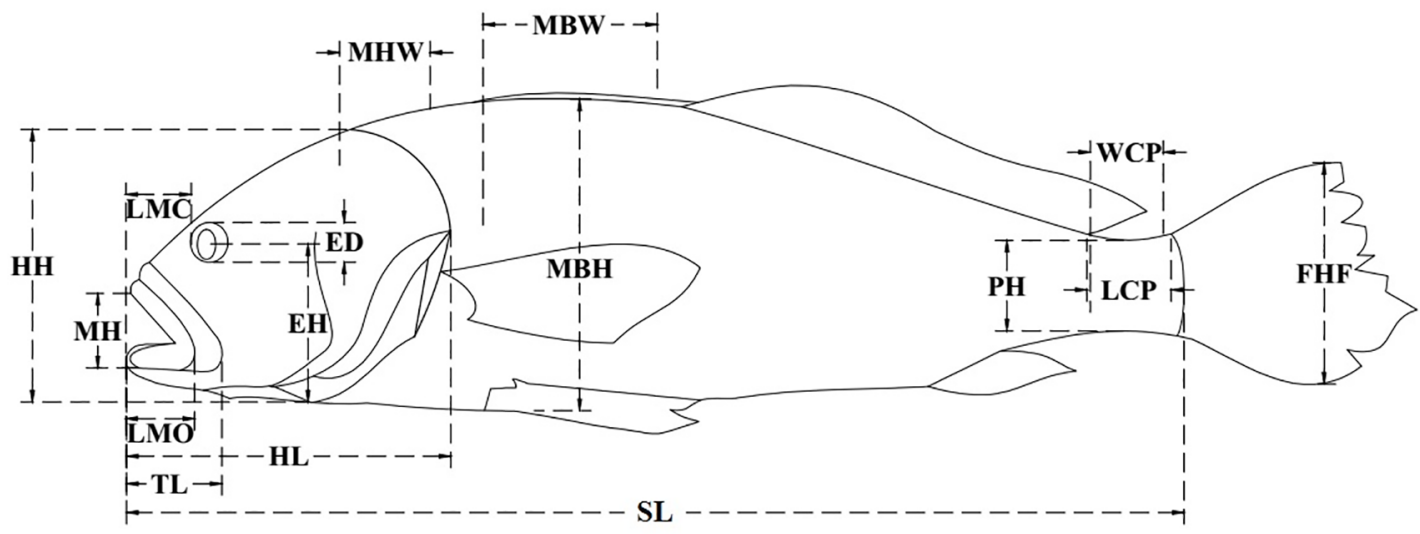

Figure 2. Morphometric measures taken on each fish, where: standard length (SL); head length (HL); head height (HH); maximum body height $(\mathrm{MBH})$; maximum body width (MBW); maximum head width (MHW); eye height (EH); eye diameter (ED); eye area (EA), determined as $\pi^{*} \mathrm{r}^{2}$; width of mouth (WM); mouth height (MH); length of muzzle closed (LMC); length of muzzle open (LMO); tooth length (TL); length of caudal peduncle (LCP); peduncle height (PH); width caudal peduncle (WCP), and fin height flow (FHF).

Table 1. Relationship of the 13 attributes generated from the linear measurements and used in the ecomorphological analyzes.

\begin{tabular}{|c|c|c|c|c|}
\hline Ecomorphological Attributes & Code & Formula & Description & Author \\
\hline Compression index & $\mathrm{CI}$ & $(\mathrm{MBH}) /(\mathrm{MBW})$ & $\begin{array}{l}\text { High values indicate lateral compression } \\
\text { of the fish, which is expected when they } \\
\text { occupy habitats with low water velocity. }\end{array}$ & $\begin{array}{l}\text { (Gatz, 1979a; Watson \& Balon, } \\
\text { 1984; Pouilly et al., 2003) }\end{array}$ \\
\hline Relative position of eyes & RPE & $(\mathrm{EH}) /(\mathrm{HH})$ & Perception of food and preferential habitat. & (Gatz, 1979a) \\
\hline Relative area of eye & RAE & $(\mathrm{EA}) /(\mathrm{SL})$ & $\begin{array}{l}\text { Perception of food, position in water } \\
\text { column. }\end{array}$ & (Gatz, 1979a) \\
\hline Relative width of head & RHW & (MHW)/(MBW) & Particle size of food and prey size. & $\begin{array}{l}\text { (Winemiller, 1991; Willis et al., } \\
\text { 2005) }\end{array}$ \\
\hline Relative height of head & RHH & $(\mathrm{HH}) /(\mathrm{MBH})$ & Particle size of food and prey size. & $\begin{array}{l}\text { (Winemiller, 1991; Willis et al., } \\
\text { 2005) }\end{array}$ \\
\hline Appearance of the mouth & $\mathrm{AM}$ & $(\mathrm{MH}) /(\mathrm{WM})$ & Type of prey. & (Beaumord, 1991) \\
\hline Relative opening of the mouth & ROM & $(\mathrm{TL}) /(\mathrm{SL})$ & Particle size of food and prey size. & (Teixeira \& Bennemann, 2007) \\
\hline Protrusion index & PI & $(\mathrm{LMC}) /(\mathrm{LMO})$ & Particle size of food and prey size. & $\begin{array}{l}\text { (Gatz, 1979a; Cochran- } \\
\text { Biederman \& Winemiller, 2010) }\end{array}$ \\
\hline Peduncle compression Index & PCI & $(\mathrm{PH}) /(\mathrm{WCP})$ & $\begin{array}{l}\text { Swimming type, affecting performance in } \\
\text { starts. }\end{array}$ & (Watson \& Balon, 1984) \\
\hline
\end{tabular}

Euclidean distances estimated on the ecomorpohological attributes estimates. This analysis tests the hypothesis of divergence among fish species by the centroid of estimated distance measures (Anderson \& Walsh 2013).

A Partial Mantel test was used to test the hypothesis that diet and morphology of these species are not correlated. This test was performed using three distance matrices: (i) using feeding of items as raw data to estimate Bray-Curtis distances, (ii) employing ecomorphological attributes as raw data and estimates of Euclidean distance and (iii) using phylogenetic distances among species following Tamura et al. (2004) and Tamura et al. (2013). The Partial Mantel test estimated the partial correlation between distances matrixes measured among feeding items and ecomorphological attributes conditioned to the phylogenetic distance matrix.

All analyses were done using the package Vegan (Oksanen et al. 2011) in the software R (R Development Core Team, 2012).

\section{Results}

In total, we examined 187 stomachs from the eight fish species. Of these, 27 were empty and 61 contained completely digested feeding items so were not included in the analyses. The analyses were 
performed on the remaining 99 fish. Stomach items of these 99 fish were identified and fish was the most consumed food item for five of the eight predatory species (Table 2). Of these predators, $P$. squamosissimus, $H$. scomberoides, and C. monoculus exhibited a high level of consumption of shrimp. Only P. nattereri showed a substantial consumption of fruit/ seeds and other feeding items (Table 2).

The first PCA, using RV of feeding items as descriptors, generated two principal components explaining $82.79 \%$ of the variance, with shrimp, fruit/seed and others contribution for the first axis; and fish, shrimp and others for the secondary axis (Table 3 ). The first component (PC1) explained $45.68 \%$ of the variance with $P$. squamosissimus, $H$. scomberoides and C. monoculus exhibiting the high positive score, due to their higher preference for shrimp, and $P$. nattereri exhibiting the most negative score, due to their diet including fruits, seeds and others items (Fig. 3). The second principal component (PC2) explained $37.11 \%$ of the variance and discriminated $H$. malabaricus and $P$. nattereri with high fish consumption (Fig. 3).

The estimated mean of the ecomorphological attributes for species and their standard deviation are seen in Table 4. The PCA using the ecomorphological attributes as descriptors created two first components explaining $90.58 \%$ of the variance. The first component concentrated $47.89 \%$ of the variance and discriminated, in opposing quadrants, a group associated with prey sizes and swimming ability, composed of high bodied fishes as $S$. rhombeus and $P$. nattereri, from a group related to the type of prey, composed of $R$. vulpinus and $H$. scomberoides (Fig. 4). The second component explained $42.69 \%$ of the variance. It was efficient to discriminate four species by their hydrodynamics: H. malabaricus, A. falcirostris, P. squamosissimus and C. monoculus, from some species with high maneuverability, such as the two piranha species, S. rhombeus and P. nattereri, (Fig. 4).

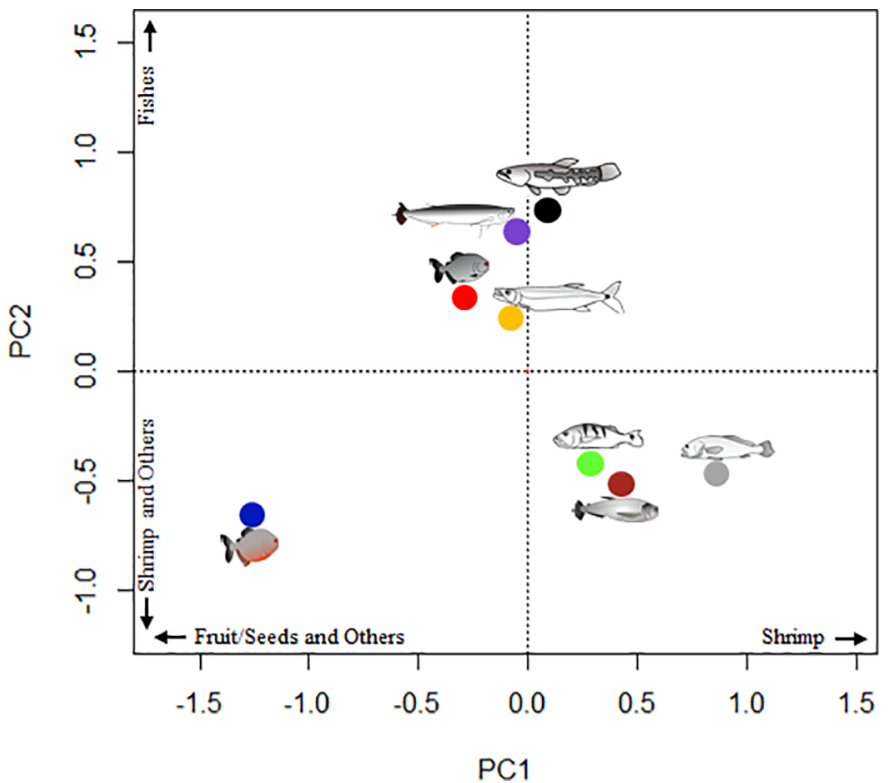

Figure 3. Results of the Principle Components Analysis, with the matrix of indices being dietary sources for eight fish species, identified as: Rhaphiodon vulpinus, Hydrolycus scomberoides, Serrasalmus rhombeus, Pygocentrus nattereri, Acestrorhynchus falcirostris, $\bigcirc$ Hoplias malabaricus, $\bigcirc$ Plagioscion squamosissimus and Cichla monoculus.

Corroborating the patterns observed in both PCAs, the perMANOVA did not provide evidence for differences among species by their feeding items ( $\mathrm{pseudo}-\mathrm{F}=0.947, \mathrm{df}=1,6, \mathrm{p}>0.05$ ). The second perMANOVA, however, yielded significant differences among these eight species using their ecomorphological attributes (pseudo-F $=30.796$, df $=1$, $136, \mathrm{p}<0.05)$.

Table 2. Index of Food Importance (IFI) of eight predatory species. For each species listed, it includes the number of stomachs with analyzed gastric content (N); and variation of the standard length (SL) of the individuals analyzed.

\begin{tabular}{|c|c|c|c|c|c|c|c|}
\hline \multirow[b]{2}{*}{ Species } & \multicolumn{7}{|c|}{ Index of Food Importance (\%) } \\
\hline & $\mathbf{N}$ & SL (mín-máx) & Fish & Insects & Shrimp & Fruit/Seeds & Others \\
\hline Acestrorhynchus falcirostris & 5 & $20.5-32.5$ & 86.84 & 0 & 10.53 & 0 & 2.63 \\
\hline Cichla monoculus & 25 & $20.5-34.5$ & 37.97 & 0.25 & 55.58 & 0 & 6.2 \\
\hline Plagioscion squamosissimus & 9 & $18-24$ & 7.55 & 2.83 & 89.15 & 0 & 0.47 \\
\hline Serrasalmus rhombeus & 16 & $13.5-18$ & 91.88 & 0.88 & 0.22 & 1.64 & 5.37 \\
\hline Pygocentrus nattereri & 20 & $15.5-19.5$ & 54.86 & 0.75 & 4.4 & 10.55 & 29.44 \\
\hline
\end{tabular}

Table 3. Principal component analysis results for the first two axes calculated for the food items.

\begin{tabular}{|c|c|c|}
\hline food items & PC 1 & PC 2 \\
\hline Fish & -0.5048 & 0.9393 \\
\hline Insects & 0.3037 & 0.5432 \\
\hline Shrimp & 0.8126 & -0.7161 \\
\hline Fruit/Seed & -0.9517 & -0.3691 \\
\hline Others & -0.8884 & -0.6076 \\
\hline Variance (\%) & $45.68 \%$ & $37.11 \%$ \\
\hline Total variance & & 82.79 \\
\hline
\end{tabular}


Cardoso, D.C. et al.

Table 4. Estimated values of mean and standard deviation of 13 ecomorphological attributes obtained from eight predatory species, including abundance of species $(\mathrm{N})$, and amplitude of the standard length (SL) of the species.

\begin{tabular}{|c|c|c|c|c|c|c|c|c|}
\hline \multirow[b]{2}{*}{ Attributes } & \multicolumn{8}{|c|}{ Species } \\
\hline & $\begin{array}{c}\text { A. } \\
\text { falcirostris }\end{array}$ & $\begin{array}{c}\text { H. } \\
\text { malabaricus }\end{array}$ & $\begin{array}{c}\text { C. } \\
\text { monoculus }\end{array}$ & $\begin{array}{c}P . \\
\text { squamosissimus }\end{array}$ & $\begin{array}{c}H . \\
\text { scomberoides }\end{array}$ & $\begin{array}{c}R . \\
\text { vulpinus }\end{array}$ & $\begin{array}{c}P . \\
\text { nattereri }\end{array}$ & $\begin{array}{c}S . \\
\text { rhombeus }\end{array}$ \\
\hline RPE & $0.67 \pm 0.05$ & $0.74 \pm 0.10$ & $0.74 \pm 0.03$ & $0.67 \pm 0.04$ & $0.69 \pm 0.04$ & $0.74 \pm 0.07$ & $0.60 \pm 0.04$ & $0.60 \pm 0.04$ \\
\hline RAE & $0.05 \pm<0.01$ & $0.03 \pm<0.01$ & $0.10 \pm 0.01$ & $0.05 \pm<0.01$ & $0.06 \pm<0.01$ & $0.05 \pm<0.01$ & $0.06 \pm 0.01$ & $0.07 \pm 0.01$ \\
\hline RHH & $0.73 \pm 0.06$ & $0.69 \pm 0.03$ & $0.72 \pm 0.03$ & $0.75 \pm 0.04$ & $0.58 \pm 0.06$ & $0.75 \pm 0.08$ & $0.60 \pm 0.04$ & $0.51 \pm 0.03$ \\
\hline RHL & $0.28 \pm<. .01$ & $0.30 \pm 0.02$ & $0.33 \pm<0.01$ & $0.30 \pm 0.01$ & $0.24 \pm 0.06$ & $0.19 \pm<0.01$ & $0.34 \pm 0.05$ & $0.33 \pm 0.01$ \\
\hline RMW & $0.07 \pm 0.01$ & $0.13 \pm 0.02$ & $0.16 \pm 0.01$ & $0.15 \pm 0.01$ & $0.08 \pm 0.02$ & $0.05 \pm 0.01$ & $0.13 \pm 0.01$ & $0.11 \pm<0.01$ \\
\hline RHM & $0.17 \pm 0.01$ & $0.16 \pm 0.01$ & $0.18 \pm<0.01$ & $0.16 \pm 0.01$ & $0.24 \pm 0.01$ & $0.18 \pm 0.01$ & $0.15 \pm 0.01$ & $0.14 \pm 0.03$ \\
\hline PCI & $1.39 \pm 0.17$ & $2.01 \pm 0.16$ & $1.40 \pm 0.10$ & $1.63 \pm 0.26$ & $2.19 \pm 0.21$ & $1.69 \pm 0.28$ & $1.81 \pm 0.23$ & $1.82 \pm 0.44$ \\
\hline $\mathrm{N}$ & 15 & 7 & 20 & 21 & 9 & 11 & 32 & 23 \\
\hline SL & $20.5-32.5$ & $19-28$ & $20.5-34.5$ & $18-24$ & $15-22.5$ & $26-37.5$ & $15.5-19.5$ & $13.5-18$ \\
\hline
\end{tabular}

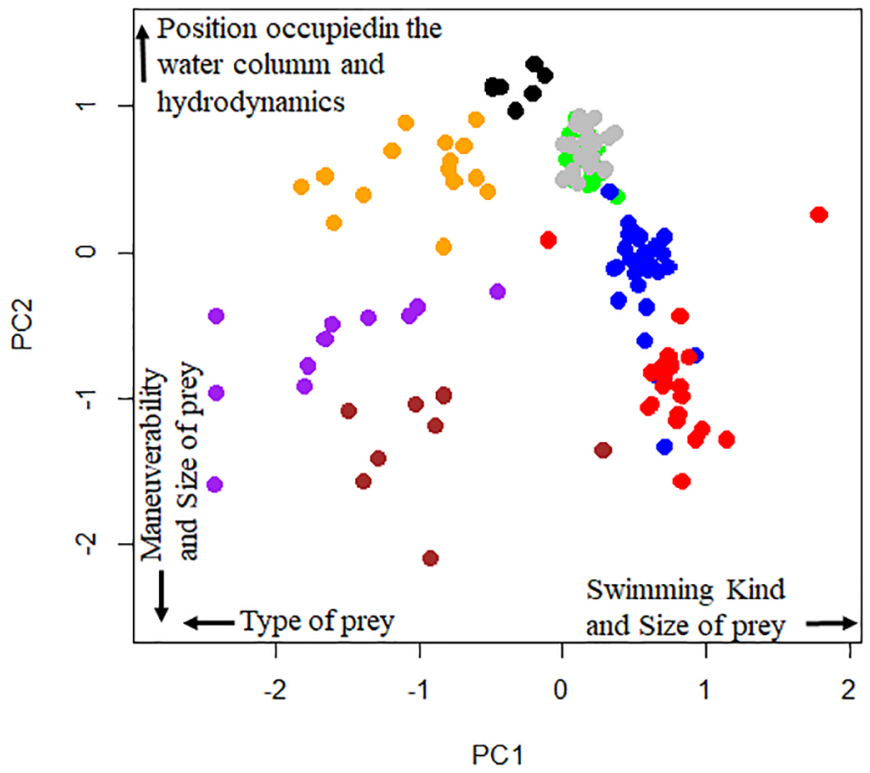

Figure 4. Bi-plot with the two first principal components of the PCA developed using the ecomorphological attributes of the eight species, where: $O$ Rhaphiodon vulpinus, Hydrolycus scomberoides, Serrasalmus rhombeus, Pygocentrus nattereri, Acestrorhynchus falcirostris, $\bigcirc$ Hoplias malabaricus, $\bigcirc$ Plagioscion squamosissimus and Cichla monoculus.

The Partial Mantel test did not uncover any correlation between the distance matrixes based on feeding items and ecomorphological attributes ( $\mathrm{r}=-0.036 ; \mathrm{P}=0.572$, using 999 permutations), when controlling for the phylogenetic effect.

\section{Discussion}

The eight species addressed in this study showed distinct ecomorphogical characteristics, indicating a potential use of different food resources. Nevertheless, no correlation between morphology and diet was found. The index of food importance discriminated these species into two groups: a first one, composed of piscivorous species: $A$. falcirostris, H. malabaricus, R. vulpinus, S. rhombeus, and P. nattereri; and, a second one comprising carnivores with a high preference for shrimp: C. monoculus, $P$. squamosissimus, and $H$. scomberoides. Of the piscivorous species, the piranha $P$. nattereri displayed dietary preferences different than those expected, and included significant quantities of vegetative material in its diet. In general, piranhas can and did display a broad spectrum of feeding behavior (e.g., Leão et al. 1991). In some cases, $P$. nattereri has been classified as a highly specialized piscivore due its phenotypic characteristics, but retains an ability to explore other feeding resources available in the environment (Piorski et al. 2005, Prudente et al. 2016). Both piranha species have short and laterally compressed bodies and strong anal fins, which are morphological characteristics associated with high maneuverability (Werner 1977, Breda et al. 2005). This maneuverability is particularly well-suited for complex habitats of low speed current (Werner 1977, Webb et al. 1996, Oliveira et al. 2010) such as those found in the flooded areas of Amazonian floodplains.

The other species were typically piscivorous, but likely varied greatly in their methods of ingestion. In general, $R$. vulpinus and $H$. scomberoides are able to eat whole prey due their large mouth with underslung jaw (Howes 1976, Beaumord 1991), but have also been shown to capture their prey using their long canine teeth (Howes 1976). 
Due to their large and upward-oriented mouths, these species focus prey-capture at the water surface or at the limnetic zone (Almeida et al. 1997, Saint-Paul et al. 2000). A similarly uniquely adapted species is that of $A$. falcirostris. These fish have highly hydrodynamic bodies and are able to reach high swimming speeds to capture their prey (Webb 1984, Breda et al. 2005), focusing primarily in the pelagic areas (Werner 1977).

The second group includes shrimp-eaters, such as P. squamosissimus, which eats shrimp during the season of its high abundance (Merona \& Rankin-de-Merona 2004, Costa et al. 2016). These fish change their diet to a focus on fish and insects when shrimp availability declines (Hahn et al. 1997). There is some controversy about the diet of C. monoculus. While some researchers propose that this species is a highly specialized piscivore (Rabelo \& Araújo-Lima 2002, Mérona \& Rankin-de-Mérona 2004), others contest that its diet is focused on shrimp (Teixeira \& Bennemann 2007). Our ecomorphological analysis suggests that both feeding strategies may be occurring, but that the strategy employed may change due to seasonal conditions, which could be tested in future studies. Given their morphologies, both P. squamosissimus and C. monoculus are efficient swimmers and are capable of expanding their mouths to ingest entire prey (Rodrigues \& Menin 2006, Teixeira $\&$ Bennemann 2007). These characteristics allow these species to exploit the most accessible and abundant feeding items, which could change seasonally from fish to shrimp, insects, among others (Merona \& Rankin-de-Mérona 2004, Prudente et al. 2016).

The ecomorphological attributes-based analyses also discriminates groups, but this discrimination does not exhibit a clear relationship with diet, and thus suggests that fish assemblages are more influenced by spatial structure than by trophic structure (Silva-Camacho et al. 2014). Previously published studies in this area exploring the relationship between fish morphology and diet have also proven inconclusive (Felley 1984, Douglas \& Matthews 1992, Teixeira \& Bennemann 2007). While some studies found close associations (Sampaio et al. 2013, Prado et al. 2016), others found no relationship (Felley 1984, Motta et al. 1995, Silva-Camacho et al. 2014). Conceptually, it could be assumed that when a relationship between morphology and diet is observed, the fish assemblage is ecomorphologically structured (Douglas \& Matthews 1992, Breda et al. 2005, Oliveira et al. 2010). In these circumstances, it should be possible to predict resource use based on animal morphology (Gatz Jr. 1979, Watson \& Balon 1984, Winemiller 1991, Oliveira et al. 2010). In the absence of such a relationship, the morphological structure could be defined by phylogenetic relationships (Oliveira et al., 2010).

The phylogenetic effect was controlled in this study by applying the Partial Mantel Test and seems not to be a key driver of the ecomorphological discrepancies observed here. Although not addressed by the current study, an alternative hypothesis to be tested in the future to explain this absence of correlation between morphology and diet could be that that these factors are more closely associated with prey availability (e.g., Hugueny \& Pouilly 1999). This is a more plausible explanation, as that study was conducted on species within the same trophic guild and our study included only carnivorous fish. Nevertheless, this result could also originate from the difficulty inherent in identifying digested prey. In general, the identification was made only to the level of upper taxonomic groups (e.g., fish, insect, and shrimp) on which high niche overlapping is observed.
Given the absence of a close relationship between diet and morphology, we propose that prey capture by predator fish in Amazonian floodplains is mainly a process driven by the opportunistic behavior of the predator coupled with food availability, as observed by Dias et al. (2017). These opportunistic behaviors could be associated with predator traits such as hydrodynamics, maneuverability, and the position in the water column where the fish preferentially live, which are all related to their morphology.

\section{Acknowledgements}

CECF was funded by CNPq (grant 302807/2015-2) and INCT ADAPTA, FKSS by CNPq (grant 457213/2014-0) and DC Cardoso received time graduate fellowship from CAPES.

\section{Author Contributions}

Diogo Campos Cardoso - Contribution to in the concept and design of the study; data collection; data analysis and interpretation; manuscript preparation.

Pieter deHart - Contribution to data analysis and interpretation, critical revision, adding intelectual content.

Carlos Edwar de Carvalho Freitas - Contribution in the concept and design of the study; data analysis and interpretation; critical revision, adding intelectual content.

Flávia Kelly Siqueira-Souza - Contribution in the concept and design of the study; to data analysis and interpretation; to manuscript preparation; adding intelectual content.

\section{Conflicts of interest}

The author(s) declare(s) that they have no conflict of interest related to the publication of this manuscript.

\section{References}

ABRAMS, P.A. 2006. Specialist-generalist competition in variable environments: the consequences of competition between resources. In: The impact of environmental variability on ecological systems (D. Vasseur \& K. McCann, eds. Fundamental ecology, Vol. 2). Springer, New York.

ADITE, A. \& Winemiller, K.O. 1997. Trophic ecology and ecomorphology of fish assemblages in coastal lakes of Benin, W Af. Ecoscience. 4(1):6-23.

AGOSTINHO, A.A. HAHN, N.S. GOMES, L.C. \& BINI, L.M. 1997. Estrutura trófica. In: A planície de inundação do alto rio Paraná: aspectos físicos, biológicos e socioeconômicos. (A.E.A.M. Vazzoler, A.A. Agostinho \& N.S. Hann, eds). Maringá: EDUEM. 229-248.

ALMEIDA, V.L.L. HAHN, N.S. \& VAZZOLER, A.E.A.M. 1997. Feeding patterns in five predatory fishes of the high Paraná river floodplain (PR, Brazil). Ecol Freshw Fish. 6(3):123-133.

AMADIO, S.A, \& BITTENCOURT, M. M. 2005. Táticas reprodutivas de peixes em ambientes de várzea na Amazônia Central. Jean François Renno Carmen García Fabrice Duponchelle Jésus Nuñez, 65.

ANDERSON, M.J. \& WALSH, D.C.I. 2013. PERMANOVA, ANOSIM, and the Mantel test in the face of heterogeneous dispersion: what null hypothesis are you testing? Ecol Monogr. 83(4): 557-574.

ANJOS, M.B. OLIVEIRA, R.R. \& ZUANON, J. 2008. Hypoxic environment as refuge against predatory fish in the Amazonian floodplain. Braz J Biology. 68(1): 45-50 
BEAUMORD, A.C. 1991. As comunidades de peixes do rio Manso, Chapada dos Guimarães, MT: uma abordagem ecológica numérica. Unpublished $\mathrm{Ph}$. D. Dissertation. Instituto de Biociências Carlos Chagas. UFRJ, 108p.

BREDA, L. OLIVEIRA, E.F. \& GOULART, E. 2005. Ecomorfologia de locomoção de peixes com enfoque para espécies neotropicais. Acta SciBiological Sciences. 27(4):371-381.

CARVALHO, F. POWER, M. FORSBERG, B.R. CASTELLO, L. MARTINS, E.G. \& FREITAS, C.E.C. 2017. Trophic ecology of Arapaima sp. in a ria lake-river-floodplain transition zone of the Amazon. Ecol Freshw Fish. 2791):237-246.

CARVALHO, P. BINI, L.M. THOMAZ, S.M. OLIVEIRA, L.G. ROBERTSON, B. TAVECHIO, W.L.G. \& DARWISCH, A.J. 2001. Comparative limnology of South American floodplain lakes and lagoons. Acta Sci. 23(2):265-273.

CATELLA, A.C. \& PETRERE Jr. M. 1996. Feeding patterns in a fish community of Baia da Onça floodplain lake of the Aquidauana River, Pantanal, Brazil. Fisheries Manag Ecol. 3(3): 229-237.

COCHRAN-BIEDERMAN, J.L. \& WINEMILLER, K.O. 2010. Relationships among habitat, ecomorphology and diets of cichlids in the Bladen River, Belize. Environ Biol Fish. 88(2): 143-152.

CORREA, S.B. \& WINEMILLER. K.O. 2014. Niche partitioning among frugivorous fishes in response to fluctuating resources in the Amazonian floodplain forest. Ecology. 95(1):210-224

CORREA, S.B. CRAMPTON, W.G.R. CHAPMAN, L.J. \& ALBERT, J.S. 2008. A comparison of flooded Forest and floating meadow fish assemblages in an upper Amazon floodplain. J Fish Biol. 72(3):629-644.

COSTA, T.V. DE MATTOS, L.A. \& MACHADO, N.D.J.B. 2016. Estrutura populacional de Macrobrachium amazonicum em dois lagos de várzea da Amazônia. Bol Inst de Pesca. 42(2):281-293.

CSÁNYI, V. \& DÓKA, A. 1993. Learning interactions between prey and predator fish. Mar Behav Physiol. 23(1-4): 63-78.

DIAS, R.M. ORTEGA, J.C.G. GOMES, L.C. \& AGOSTINHO, A.A. 2017. Trophic relationships in fish assemblages of Neotropical floodplain lakes: selectivity and feeding overlap mediated by food availability. Iheringia. Ser Zool. 107.

DOUGLAS, M.E. \& MATTHEWS, W.J. 1992. Does morphology predicts ecology? Hypothesis testing within a fish assemblage. Oikos. 65(2):213-224.

DUARTE, C. PY-DANIEL, L.H.R. \& DE DEUS, C.P. 2010. Fish assemblages in two Sandy in lower Purus river, Amazonas, Brazil. Ilheringa, Sér. Zool. 100(4):319-328.

FELLEY, J.D. 1984. Multivariate identification of morphological - environmental relationships within the Cyprinidae (Pisces). Copeia. 1984(2):442-455.

FREITAS, C.E.C. COSTA, E.L. \& SOARES, M.G.M. 2005. Ecomorphological correlates of thirteen dominant fish species of Amazonian floodplain lakes. Acta Limnol Bras. 17(3):339-347.

FREITAS, C.E.C. SIQUEIRA-SOUZA, F.K. FLORENTINO, A.C. HURD, L.E. 2014. The importance of spatial scales to analysis of fish diversity in Amazonian floodplain lakes and implications for conservation. Ecol Freshw Fish. 23(3):470-477.

FREITAS, C.E.C. SIQUEIRA-SOUZA, F.K. PRADO, K.L.L. YAMAMOTO, K.C. \& HURD, L.E. 2010. Factors determining fish species diversity in Amazonian floodplain lakes. In: Amazon Basin: Plant life, Wildlige and Environment (N. Rojas \& R. Prieto, eds). Science Publishers. New York, USA. pp 41-76.

GATZ Jr., A.J. 1979. Community organization in fishes as indicated by morphological features. Ecology. 60(4):711-718.

HAHN, N.S. AGOSTINHO, A.A. \& GOITEIN. R. 1997. Feeding ecology of curvina Plagioscion squamosissimus (Heckel, 1940) (Osteichthyes, Perciformes) in the Itaipu Reservoir and Porto Rico floodplain. Acta Limnol Bras. 9(1):11-22.

HEINLEIN, J.M. STIER, A.C. \& STEELE, M.A. 2010. Predators reduce abundance and species richness of coral reef fish recruits via non-selective predation. Coral Reefs. 29(2):527-532.
HOWES, G.J. 1976. The cranial musculature and taxonomy of characoid fishes of the tribes Cynodontini and Characini. Bull Br Mus (Nat Hist). Zool. 29: 203-248.

HUGUENY, B. \& POUILLY, M. 1999. Morphological correlates of diet in an assemblage of West African freshwater fishes. J Fish Biol. 54(6):1310-1325.

HYNES, H.B.N. 1950. The food of fresh-water sticklebacks (Gasterosteus aculeatus and Pygosteus pungitius) with a review of methods used in studies of the food of fishes. J Anim Ecol. 19(1):36-58.

HYSLOP, E.J. 1980. Stomach contents analysis - a review of methods and their applications. J Fish Biol. 17(4):411-429.

JUNK, W.J. BAYLEY, P.B. \& SPARKS, R.E. 1989. The flood pulse concept in river-floodplain systems. Can J Fish Aquat Sci. 106(1):110-127.

JUNK, W.J. PIEDADE, M.T.F. SCHÖNGART, J. COHN-HAFT, M. ADENEY, J.M. \& WITTMANN, F. 2011. A classification of major naturally-occurring Amazonian lowland wetlands. Wetlands 31(4): 623-640.

KAWAKAMI, E. \& VAZZOLER, G. 1980. Método gráfico e estimativa de índice alimentar aplicado no estudo de alimentação de peixes. Bolm Inst Oceanogr. 29(2): 205-207.

KEAST, A. WEBB, D. 1966. Mouth and body form relative to feeding ecology in the fish fauna of a small lake, Lake Opinicon, Ontario. J Fish Board Can. 23(12):1845-1874.

KING, J.R. \& JACKSON, D.A. 1999. Variable selection in large environmental data sets using principal components analysis. Environmetrics. 10(1):67-77.

LEÃO, E.L.M. LEITE, R.G. CHAVES, P.T.C. \& FERRAZ, E. 1991. Aspectos da reprodução, alimentação e parasitofauna de uma espécie rara de piranha, Serrasalmus altuvei (Ramírez, 1965) (Pisces, Serrasalmidae) do baixo Rio Negro. Rev Bras Biol. 51(3):545-553.

LOWE-MCCONNELL, R.H. 1999. Estudos ecológicos de comunidades de peixes tropicais. Editora USP, São Paulo, SP.

LUZ-AGOSTINHO, K.D.G. AGOSTINHO, A.A. GOMES, L.C. \& JULIO JR. H.F. 2008. Influence of flood pulses on diet composition and trophic relationships among piscivorous fish in the upper Paraná river floodplain. Hydrobiologia. 607(1):187-198

MAZZONI R, M.M. REZENDE, C.F. \& MIRANDA, J.C. 2010. Alimentação e padrões ecomorfológicos das espécies de peixes de riacho do alto rio Tocantins, Goiás, Brasil. Iheringia Ser Zool. 100(2):162-168.

MCCUNE, B. \& MEFFORD, M.J. 1997. PC-ORD. Multivariate Analysis of Ecological Data. Version 3,0. MjM Software. Oregon. Gleneden Beach.

MÉRONA, B. \& RANKIN-DE-MÉRONA, J. 2004. Food resource partitioning in a fish community of the central Amazon floodplain. Neotrop Ichthyol. 2(2):75-84.

MOTTA, P.J. NORTON, S.F. \& LUCZKOVICH, J.J. 1995. Perspectives on the ecomorphology of bony fishes. Environ Biol Fish. 44(1-3): 11-20.

NOWLIN, W.H. DRENNER, R.W. GUCKENBERGER, K.R. LAUDEN, M.A. ALONSO, G.T. JOSEPH, E.F. \& SMITH, J.L. 2006. Gape limitation, prey size refuges and top down impacts of piscivorous largemouth bass in shallow pond ecosystem. Hydrobiologia. 563(1):357-369.

OKADA, E.K. AGOSTINHO, Â.A. PETRERE JR. M. \& PENCZAK, T. 2003. Factors affecting fish diversity and abundance in drying ponds and lagoons in the upper Paraná River basin, Brazil. Ecohydrology and Hydrobiology 3(1):97-110.

OKSANEN, J. GUILLAUME BLANCHET, F. KINDT, R. LEGENDRE, P. O'HARA, R.B. SIMPSON, G.L. SOLYMOS, P. STEVENS, M.H.H. \& VAGNER, H. 2011. Vegan: Community Ecology Package version 1: 7-9. http://CRAN.R-project.org/package= =vegan

OLIVEIRA, E.F. GOULART, E. BREDA, L. MINTE-VERA, C.V. PAIVA, L.R.D.S. \& VISMARA, M.R. 2010. Ecomorphological patterns of the fish assemblage in a tropical floodplain: effects of trophic, spatial and phylogenetic structures. Neotrop Ichthyol 8(3):569-586.

PAGOTTO, J.P.A. GOULART, E. OLIVEIRA, E.F. \& YAMAMURA, C.B 2011. Trophic ecomorphology of Siluriformes (Pisces, Osteichthyes) from a tropical stream. Braz J Biol. 71(2):469-479. 
PETRY, A.C. GOMES, L.C. PIANA, P. AGOSTINHO, A.A. 2010. The role of the predatory trahira (Pisces: Erythrinidae) in structuring fish assemblages in lakes of a Neotroplical floodplain. Hydrobiologia. 651(1):115-126.

PIORSKI, N.M. ALVES, J.D.R.L. MACHADO, M.R.B. \& CORREIA, M.M.F. 2005. Alimentação e ecomorfologia de duas espécies de piranhas (Characiformes: Characidae) do lago de Viana, estado do Maranhão, Brasil. Acta Amazon. 35(1): 63-70.

POUILLY, M. LINO, F. BRETENOUX, J.G. \& ROSALES, C. 2003. Dietarymorphological relationships in a fish assemblage of the Bolivian Amazonian floodplain. J Fish Biol. 62(5): 1137-1158.

PRADO, A.V. GOULART, E. \& PAGOTTO, J. 2016. Ecomorphology and use of food resources: inter-and intraspecific relationships of fish fauna associated with macrophyte stands. Neotrop Ichthyol (Online) 14(4).

PRUDENTE, B.S. CARNEIRO-MARINHO, P. VALENTE, R.M. \& MONTAG L.F.A. 2016. Feeding ecology of Serrasalmus gouldingi (Characiformes: Serrasalmidae) in the lower Anapu River region, Eastern Amazon, Brazil. Acta Amazon. 46(3):259-270.

R DEVELOPMENT CORE TEAM 2012 R: A language and environment for statistical computing. R Foundation for Statistical Computing: Vienna, Austria. ISBN 3-900051-07-0. Available online at http://CRAN.Rproject.org

RABELO, H. ARAÚJO-LIMA, C.A.R.M. 2002. A dieta e o consumo diário de alimento de Cichla monoculus na Amazônia Central. Acta Amazon. 32(4):707-724.

REIS, R.E. ALBERT, J.S. DARIO, F.D. MINCARONE, M.M. PETRY, P. \& ROCHA, L.A. 2016. Fish diversity and conservation in South America. J Fish Biol. 89(1):12-47.

RODRIGUES, S.S. MENIN, E. 2006. Adaptações anatômicas da cavidade bucofaringeana de Pseudoplatystoma corruscans (Spix e Agassiz, 1829) (Siluriformes, Pimelodidae) em relação ao seu hábito alimentar. Rev Ceres. 53(305):135-146.

RODRIGUEZ, M.A. LEWIS, W.M. 1997. Structure of fish assemblages along environmental gradients in floodplain lakes of the Orinoco River. Ecol Monographs. 67(1):109-128.

SAINT-PAUL, U. ZUANON, J.A. CORREA, M.A.V. GARCÍA, M. FABRÉ, N.N. BERGER, U. \& JUNK, W.J. 2000. Fish communities in central Amazonian white-and blackwater floodplains. Environ Biol Fish. 57(3):235250.

SAMPAIO, A.L.A. PAGOTTO, J.P.A. \& GOULART, E. 2013. Relationships between morphology, diet and spatial distribution: testing the effects of intra and interspecific morphological variations on the patterns of resource use in two Neotropical Cichlids. Neotrop Ichthyol 11(2):351-360.

SÁNCHEZ-BOTERO, J.I. FARIAS, M.L. PIEDADE, M.T. \& GARCEZ, D.S 2003. Ictiofauna associada às macrófitas aquáticas Eichhornia azurea (SW.) Kunth. e Eichhornia crassipes (Mart.) Solms. no lago Camaleão, Amazônia Central, Brasil. Acta Sci Biol Sci. 25: 369-375.

SCHOENER, T.W. 1971. Theory of feeding strategies. Annu Rev Ecol Syst. 2(1):369-404.

SILVA-CAMACHO, D.S. SANTOS, J.N.S. GOMES, R.S. \& ARAÚJO, F.G. 2014. Ecomorphological relationships among four Characiformes fish species in a tropical reservoir in South-eastern Brazil. Zoologia. 31(1):28-34.
SIQUEIRA-SOUZA, F.K. BAYER, C. CALDAS, W.H. CARDOSO, D.C. YAMAMOTO, K.C. \& FREITAS, C.E.C. 2016b. Ecomorphological correlates of twenty dominant fish species of Amazonian floodplain lakes. Braz J Biol. 77(1):199-206.

SIQUEIRA-SOUZA, F.K. FREITAS, C.E.C. HURD, L.E. \& PETRERE, M. 2016a. Amazon floodplain fish diversity at different scales: do time and place really matter? Hydrobiologia, 776(1), 99-110.

SOARES, M.G.M. ALMEIDA, R.G. JUNK, W.J. 1986. The trophic status of the fish fauna in Lago Camaleão: a macrophyte dominated floodplain lake in the middle Amazon. Amazoniana 9(4):511-526.

SOARES, M.G.M. COSTA, E.L. SIQUEIRA-SOUZA, F.K. ANJOS, H.D.B. YAMAMOTO, K.C. \& FREITAS, C.E.C. 2007. Peixes de lagos do médio rio Solimões. EDUA, Manaus.

TAMURA, K. NEI, M. \& KUMAR, S. 2004. Prospects for inferring very large phylogenies by using the neighbor-joining method. P Natl A Sci. 101(30):11030-11035.

TAMURA, K. STECHER, G. PETERSON, D. FILIPSKI, A. \& KUMAR, S. 2013. MEGA6: Molecular Evolutionary Genetics Analysis version 6.0. Mol Biol Evol. 30(12):2725-2729.

TEIXEIRA, I. \& BENNEMANN, S.T. 2007. Ecomorfologia refletindo a dieta dos peixes em um reservatório no sul do Brasil. Biota Neotrop. 7(2): 67-76. http://www.biotaneotropica.org.br/v7n2/pt/abstract?article+bn00807022007

VAL, A.L. \& ALMEIDA-VAL, V.M.F. 1995. Fishes of the Amazon and their Environment: Physiologycal and Biochemical Aspects. Heidelberg, Springer.

VAZZOLER, A.E.A.M. 1996. Biologia da reprodução de peixes teleósteos: teoria e prática. Maringá: Eduem, 169.

WATSON, D.J. \& BALON, E.K. 1984. Ecomorphological analysis of fish taxocenes in rainforest streams of northern Borneo. J Fish Biol. 25(3):371384.

WEBB, P.W. 1984. Form and function in fish swimming. Sci. 251(1):58-68.

WEBB, P.W. LALIBERTE, G.D. \& SCHRANK, A.J. 1996. Does body and fin form affect the maneuverability of fish traversing vertical and horizontal slits? Environ Biol Fish. 46(1):7-14.

WERNER, E.E. 1977. Species packing and niche complementarity in three sunfishes. Am Nat. 111(979):553-578.

WIKRAMANAYAKE, E.D. 1990. Ecomorphology and biogeography of a tropical stream fish assemblage: evolution of assemblage structure. Ecology. 71(5):1756-1764.

WILLIS, S.C. WINEMILLER, K.O. \& LOPEZ-FERNANDEZ, H. 2005. Habitat structural complexity and morphological diversity of fish assemblages in a Neotropical floodplain river. Oecologia. 142(2): 284-295.

WINEMILLER, K.O. 1989. Ontogenetic diet shifts and resource partitioning among piscivorous fishes in the Venezuela Llanos. Environ Biol Fish. 26(3):177-199.

WINEMILLER, K.O. 1991. Ecomorphological diversification in lowland freshwater fish assemblages from five biotic regions. Ecol Monogr. 61(4):343-365.

WOOTTON, R.J. 1990. Ecology of teleost fish. Chapman \& Hall, London. 